\title{
Losses Associated with Secondary Effects in Earthquakes
}

\author{
James E. Daniell*, Andreas M. Schaefer and Friedemann Wenzel \\ Geophysical Institute, Center for Disaster Management and Risk Reduction Technology, Karlsruhe Institute of Technology, \\ Karlsruhe, Germany
}

The number of earthquakes with high damage and high losses has been limited to around 100 events since 1900. Looking at historical losses from 1900 onward, we see that around 100 key earthquakes (or around 1\% of damaging earthquakes) have caused around $93 \%$ of fatalities globally. What is indeed interesting about this statistic is that within these events, secondary effects have played a major role, causing around $40 \%$ of economic losses and fatalities as compared to shaking effects. Disaggregation of secondary effect economic losses and fatalities demonstrating the relative influence of historical losses from direct earthquake shaking in comparison to tsunami, fire, landslides, liquefaction, fault rupture, and other type losses is important if we are to understand the key causes post-earthquake. The trends and major event impacts of secondary effects are explored in terms of their historic impact as well as looking to

OPEN ACCESS

Edited by:

Nobuhito Mori,

Kyoto University, Japan

Reviewed by:

Yoshio Kajitani,

Central Research Institute of Electric Power Industry, Japan

Kaiming Bi,

Curtin University, Australia

${ }^{*}$ Correspondence: James E. Daniell j.e.daniel/@gmail.com

Specialty section:

This article was submitted to Earthquake Engineering,

a section of the journal Frontiers in Built Environment

Received: 06 February 2017 Accepted: 04 May 2017

Published: 13 June 2017

Citation:

Daniell JE, Schaefer AM and Wenzel F (2017) Losses Associated

with Secondary Effects

in Earthquakes.

Front. Built Environ. 3:30. doi: 10.3389/fbuil.2017.00030 improved ways to disaggregate them through two case studies of the Tohoku 2011 event for earthquake, tsunami, liquefaction, fire, and the nuclear impact; as well as the Chilean 1960 earthquake and tsunami event.

Keywords: tsunami, earthquake effects, socioeconomic losses, landslides, liquefaction, fatalities, economic losses, earthquake

\section{INTRODUCTION}

Disaggregation of secondary effect economic losses and fatalities demonstrating the relative influence of historical losses from direct earthquake shaking in comparison to tsunami, fire, landslides, liquefactions, fault rupture, and other type losses is important if we are to understand the key causes post-earthquake.

Existing studies have attempted to examine the key causes without putting dollar values to the losses, e.g., Bird and Bommer (2004) studied 50 earthquakes between 1980 and 2003 for all secondary effect types, Keefer (1984) and Rodriguez et al. (1999) for landslide losses, and NGDC/NOAA (2010) for tsunami losses. Although most historical losses have been earthquake shaking related, the influence of the 2011 Tohoku earthquake has changed the historical percentages significantly for tsunami, just as the 1995 Kobe and 2011 Christchurch earthquakes have with regard to liquefaction. Liquefaction has occurred in many earthquakes but this is also difficult to disaggregate for older historical earthquakes. Fire in 1906 San Francisco and 1923 Great Kanto caused significant losses, but since then, important losses have also occurred in many earthquakes. Landslide losses in Haiyuan 1920, Ancash 1970, El Salvador 2001, Kashmir 2005, and Sichuan 2008 were dominant in the database, with many other incidents causing minor damages. Quite often for smaller events, landslides deliver a great amount of the clean-up cost, and indeed sectoral losses. Infrastructure, such as roads, is particularly vulnerable to landslides and secondary effects, often causing much of the damage (i.e., Kaikoura 2016). 
This paper sets out to examine the percentage of socioeconomic losses of the secondary effects as compared to primary effects of earthquakes. It also sets out to examine the way in which secondary losses have been counted in past disasters by examining Tohoku 2011 and Chile 1960 in a fact-finding approach.

\section{METHODOLOGY}

The methodology to derive the losses due to secondary effects consists of a couple of steps:

(1) To define the different types of secondary effects

(2) To collect the data associated with the defined secondary effects types in past disasters.

\section{Defining Secondary Effects}

The primary effects of earthquakes are caused by the surface rupture along the fault and by the ground shaking via the earthquake energy release. The secondary effects are the effects that occur directly as a result of this earthquake shaking and energy release, i.e., the onset of a tsunami wave, or a landslide. Tertiary effects could include cascading effects such as the primary effect of an earthquake causing a secondary effect in the form of a tsunami which damages a nuclear power plant, and then a nuclear disaster develops. Another such tertiary effect is an epidemic or starvation due to the effects of the earthquake. The process of primary, secondary, and tertiary effects is shown in Table 1. It is very difficult to correctly differentiate between secondary and tertiary effects, and the whole sequence can sometimes simply be described as a cascading effect. The Tohoku earthquake of 2011 is a key example.

For the purposes of better defining the terms in this manuscript, the term "effects" refers to the changes to the earth's surface as a result of the earthquake (hazard-related); "losses" refer to the socioeconomic changes post-disaster be they deaths, or economic losses.

\section{Collection of Data for Earthquake Fatalities and Economic Losses from Secondary Effects}

There are many main sources of secondary effects due to earthquakes which have been collected in the literature of which will be explained via the individual parts of the definitions given above.

Landslides are induced by earthquakes where slopes lose stability as consequence of shaking, causing soil and rock masses to move downhill. This can be accentuated by rainfall and vegetation and mainly occurs in mountainous or steep sloping regions. Key factors are detailed in Khazai and Sitar (2004) examining the 1999 Chi-Chi earthquake. A study by Nadim et al. (2006) showed global landslide hotspots. In addition, a similar study has been undertaken as part of secondary effects analysis, using a combination of soil moisture indices and slopes for earthquakes worldwide to create a landslide hazard index. Godt et al. (2008) have developed a rapid loss estimation methodology for landslides worldwide as part of the PAGER project, using a PGAslope relationship based on Newmark's method via the equations
TABLE 1 | The process of primary, secondary, and tertiary effects of earthquakes.

\begin{tabular}{|c|c|c|}
\hline Type of effect & Name & Key elements \\
\hline Primary effects & Ground shaking & $\begin{array}{l}\text { - Source effects (directivity, hanging/ } \\
\text { foot wall) } \\
\text { - Path effects } \\
\text { - Site effects (soil type, location) }\end{array}$ \\
\hline \multirow[t]{8}{*}{$\begin{array}{l}\text { Secondary } \\
\text { effects }\end{array}$} & Tsunami & $\begin{array}{l}\text { - Wave height } \\
\text { - Size of fault rupture and proximity to } \\
\text { coastline }\end{array}$ \\
\hline & $\begin{array}{l}\text { Landslide, slope } \\
\text { failure }\end{array}$ & $\begin{array}{l}\text { - Slope of the location } \\
\text { - Soil typologies and stability of regolith } \\
\text { - Geological map }\end{array}$ \\
\hline & Liquefaction & $\begin{array}{l}\text { - Sand/soil type (grain size) } \\
\text { - Water table location (saturation) }\end{array}$ \\
\hline & $\begin{array}{l}\text { Changes in ground } \\
\text { level }\end{array}$ & - Ground loading \\
\hline & Fire & $\begin{array}{l}\text { - Flammability Index and susceptible } \\
\text { components }\end{array}$ \\
\hline & $\begin{array}{l}\text { Ground effects and } \\
\text { surface breaks }\end{array}$ & $\begin{array}{l}\text { - Surface effects, lateral spreading } \\
\text { - Depth of hypocenter }\end{array}$ \\
\hline & $\begin{array}{l}\text { Flooding, dam } \\
\text { breaks }\end{array}$ & $\begin{array}{l}\text { - Location of shaking with respect to } \\
\text { water bodies }\end{array}$ \\
\hline & & $\begin{array}{l}\text { - Susceptible dams and potential earth } \\
\text { locations }\end{array}$ \\
\hline \multirow[t]{4}{*}{ Tertiary effects } & Epidemics & $\begin{array}{l}\text { - Susceptibility of population and } \\
\text { climate }\end{array}$ \\
\hline & Socio-psychological & $\begin{array}{l}\text { - Age, cultural and socioeconomic } \\
\text { status }\end{array}$ \\
\hline & Economical & - Economic status of the region \\
\hline & Environmental & $\begin{array}{l}\text { - Environmental susceptibility of the } \\
\text { region }\end{array}$ \\
\hline
\end{tabular}

TABLE 2 | The effect of larger landslide events since 1900.

\begin{tabular}{lll}
\hline Date and location & Magnitude of event & Fatalities due to landslides \\
\hline 1920 Haiyuan & Mw 8.3/8.6 & 136,700 deaths $(50 \%)$ \\
1970 Ancash & Mw 7.9 & 26,700 deaths $(40 \%)$ \\
2005 Kashmir & Mw 7.6 & 26,500 deaths $(31 \%)$ \\
2008 Sichuan & Mw 7.9 & 26,500 deaths $(30 \%)$ \\
1949 Khait & Mw 7.6 & 11,760 deaths $(98 \%)$ \\
1976 Irian Jaya & Mw 7.1 & 5,520 deaths $(92 \%)$ \\
1907 Karatag & Mw 7.2 & 4,900 deaths $(35 \%)$ \\
1917 Daguan & Mw 7.3 & 1,800 deaths $(96 \%)$ \\
1950 Assam, Chayu & Mw 8.6 & 1,450 deaths $(30 \%)$ \\
1998 Badakhshan and & Mw 6.5 & 1,350 deaths $(30 \%)$ \\
Takhar Provinces & &
\end{tabular}

of Jibson (2007). Small-scale models to examine susceptibility to earthquake-triggered slope instability have been put forward by Jibson (2007) and Miles and Keefer (2009). In addition, great work during the COGEAR project was undertaken to examine historical landslide events and others even infer earthquake intensities (Beck, 2009). Parker (2013) continues to create relationships of the earthquake magnitude and ground motions vs. landslide density. A detailed study of earthquake-induced landslide losses has been undertaken by Bommer and Rodriguez (2002) and Keefer $(1984,2002)$ (Table 2).

The largest death tolls in the last 117 years from landslides have come in the Chinese 1920 Haiyuan event, where many people 


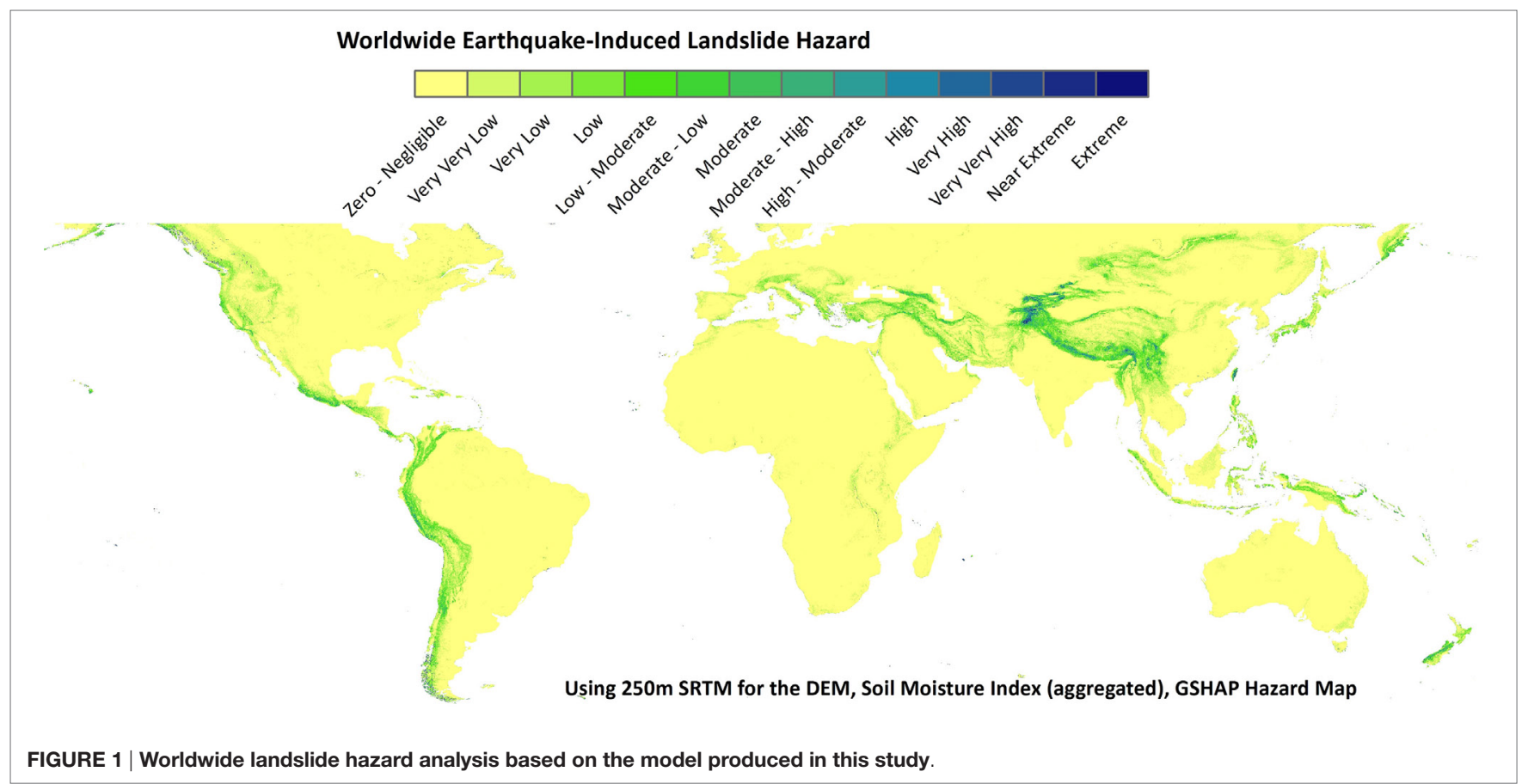

living in cave like buildings, and villages close to slopes, were buried with the M8.6 mainshock and resulting aftershocks via loess landslides.

In the study below, the slope was taken from global use of the SRTM $250^{1}$ dataset, the soil moisture index over a year from the global USDA, and the GSHAP map with historical landslides from earthquakes to calculate the landslide potential index. A landslide risk map can also be produced in conjunction with historical data and exposure. This, along with historical landslide losses, simply produces a flag system with the potential landslide susceptible areas. An example of a landslide analysis using a similar methodology is shown for Germany, Austria, and Switzerland and was calculated in Daniell et al. (2013) but with extension to estimated losses. Figure 1 shows the worldwide landslide hazard analysis produced in this study.

We will refer to quake lakes and flooding in a subsequent paragraph.

Liquefaction occurs where saturated soil (usually not too fine-grained sand) layers are turned from solid to liquid, causing rapid failure. This generally only occurs in earthquakes with the shaking inducing a loss of shear strength. One of the first studies to calculate the potential for liquefaction was the study of Seed and Idriss (1971). Generally, the problem has been tackled via empirical methods, using soil properties [Standard Penetration Test (via blowcounts)] and water table level, in order to determine the liquefaction potential. For large-scale assessment, Vs,30 (average shear wave velocity in the first $30 \mathrm{~m}$ ) has been used as a proxy to develop an equation for simplified liquefaction susceptibility (Dismuke and Mote, 2012). These can then be further classified into deterministic (Goh and Goh, 2007) and probabilistic (Cetin et al., 2002) approaches as well as into

${ }^{1}$ http://srtm.csi.cgiar.org/.
TABLE 3 | The effect of larger liquefaction events since 1900.

\begin{tabular}{|c|c|c|}
\hline Date and location & $\begin{array}{l}\text { Magnitude of } \\
\text { event }\end{array}$ & Fatalities and/or economic losses \\
\hline $\begin{array}{l}\text { 2010/2011 } \\
\text { Christchurch } \\
\text { Sequence }\end{array}$ & $\begin{array}{l}\text { Mw 7.1, Mw 6.3, } \\
\text { and subsequent } \\
\text { aftershocks }\end{array}$ & $\begin{array}{l}\text { No known fatalities, but } 6,000+ \\
\text { buildings red zoned, and many other } \\
\text { clean-up costs. Likely around } \$ 10 \mathrm{bn}+ \\
\text { associated with liquefaction losses }\end{array}$ \\
\hline 1964 Niigata & Mw 7.6 & $\begin{array}{l}2 \text { deaths, many collapses of multi- } \\
\text { storey apartments }\end{array}$ \\
\hline 1995 Kobe & Mw 6.9 & 3 deaths, widespread damage \\
\hline 1999 Izmit & Mw 7.7 & Extensive damage \\
\hline $\begin{array}{l}1935 \text { Taiwan; } 2016 \\
\text { Taiwan }\end{array}$ & Multiple & $\begin{array}{l}16 \text { deaths were believed to be } \\
\text { associated in 1935; with liquefaction } \\
\text { also believed to be a factor in the } 2016 \\
\text { quake }\end{array}$ \\
\hline $\begin{array}{l}1920 \text { Haiyuan, } \\
1989 \text { Tajikistan, } \\
2013 \text { Diexi }\end{array}$ & Multiple & $\begin{array}{l}\text { Loess liquefaction caused many } \\
\text { fatalities (included above in landslide) }\end{array}$ \\
\hline
\end{tabular}

The 1989 Loma Prieta, 1964 Alaska, 1988 Bihar, 1990 Luzon, and 1905 Malatya also saw much liquefaction although these were associated mainly with minor economic losses. Loess liquefaction caused much damage in the 1920 Haiyuan earthquake among others and has been included in the landslide component.

flow liquefaction and cyclic mobility (Kramer, 1996). For Japan, a good review of countermeasures stemming from some of the below locations has been made by Yasuda and Harada (2014). Currently, an expansion of the PAGER rapid loss system of the USGS is also considering liquefaction susceptibility following the work of Allstadt et al. (2017). Significant losses have not be seen for liquefaction globally in the form of fatalities, (except for loess liquefaction) however significant economic losses have been seen as shown in Table 3.

Tsunamis occurs where fault movement from an offshore subduction earthquake causes a large volume of water to be displaced 
either directly by fault displacement of in consequence of a triggered large subsurface landslide or a combination of both effects. The long-wavelength distortion of the water surface, typically with amplitudes in the meter range, travels at about $800 \mathrm{~km} / \mathrm{h}$ in open seas with little attenuation to large distances. Eventually, the water waves travel from deeper waters to shallow waters at the coastline, slowing the wave, increasing the amplitude, and resulting in large, destructive waves.

In recent years, the number of fatalities (Table 4) has been dominated by two large events, namely, the 2004 Indian Ocean earthquake and the 2011 Tohoku earthquake, both causing major losses due to tsunami effects. Using historical earthquakes, the

TABLE 4 | The effect of larger tsunami events since 1900.

\begin{tabular}{|c|c|c|}
\hline Date and location & $\begin{array}{l}\text { Magnitude of } \\
\text { event }\end{array}$ & Fatalities and/or economic losses ${ }^{a}$ \\
\hline 2004 Indian Ocean & Mw 9.1 & $\begin{array}{l}\text { 168,000 (Indonesia), 35,300 (Sri Lanka), } \\
\text { 15,800 (India), 8,200 (Thailand) (ca. } \\
\text { 99\%) deaths, and \$10bn+ (event year) }\end{array}$ \\
\hline 2011 Tohoku & Mw 9.0 & $\begin{array}{l}17,931 \text { deaths (96\% not including } \\
\text { indirect) } / \$ 120 b n+(\text { event year) }\end{array}$ \\
\hline $\begin{array}{l}1941 \text { Andaman } \\
\text { Islands }\end{array}$ & Mw 7.7 & 7,960 deaths $(99.5 \%)$ \\
\hline 1976 Moro Gulf & Mw 8 & 6,229 deaths (88.0\%) \\
\hline 1945 Makran & Mw 8 & 3,700 deaths $(92.5 \%)$ \\
\hline 1933 Sanriku-oki & Mw 8.4 & 3,002 deaths $(98.0 \%)$ \\
\hline $\begin{array}{l}1998 \text { Papua New } \\
\text { Guinea }\end{array}$ & Mw 7 & 2,683 deaths (100.0\%) \\
\hline 1908 Messina & Mw 7.24 & 2,578 deaths $(3.0 \%)$ \\
\hline 1992 Flores & Mw 7.7 & 2,519 deaths $(100.0 \%)$ \\
\hline 1952 Kamchatka & Mw 9.0 & 2,336 deaths (100.0\%) \\
\hline
\end{tabular}

aMedian estimate from literature and analysis. tsunami risk can be evaluated qualitatively, given the advent of a new earthquake, by using the magnitude and historical earthquakes that have occurred in that location. Global Disaster Alert and Coordination System (2011) and various tsunami warning centers also provide potential runup heights post-earthquake based on analysis; hence, these results can be used to potentially map the inundated areas and by using population, capital stock, and gross domestic product estimates, work out the affected exposure. InaSAFE (2013) and TsuDAT (2013) are two software packages reviewed that can calculate the exposed metrics and the associated losses. An example of maximum tsunami water height runup from historical tsunamis is shown with much data derived from National Geophysical Data Center (USA) as seen below in Figure 2 with the historical tsunami runups.

As computation speeds have increased in the past few years, the ability to undertake probabilistic tsunami hazard modeling on a personal computer has become possible (Schaefer et al., 2015).

Fire is a result of earthquake shaking, influencing electricity, gas, or fire sources to ignite in and around infrastructure that is in the shaking area. In the past, this has been the greatest contributor to damage in many earthquakes, including 1906 San Francisco and 1923 Great Kanto (Table 5). At present, the influence of fire is still major in earthquakes; however, with better fire management practices in effect, and less buildings built of flammable materials, this is a reducing element in total loss statistics, with the recent Tohoku earthquake only having around 150 people dying due to fire. Many earthquakes in the US, Japan, and NZ have the chance for fires due to the wooden housing typologies often used. Scawthorn et al. (2005) details various case studies in his book as one of the better fire following earthquake references. In many countries in the world, wooden frames are used including

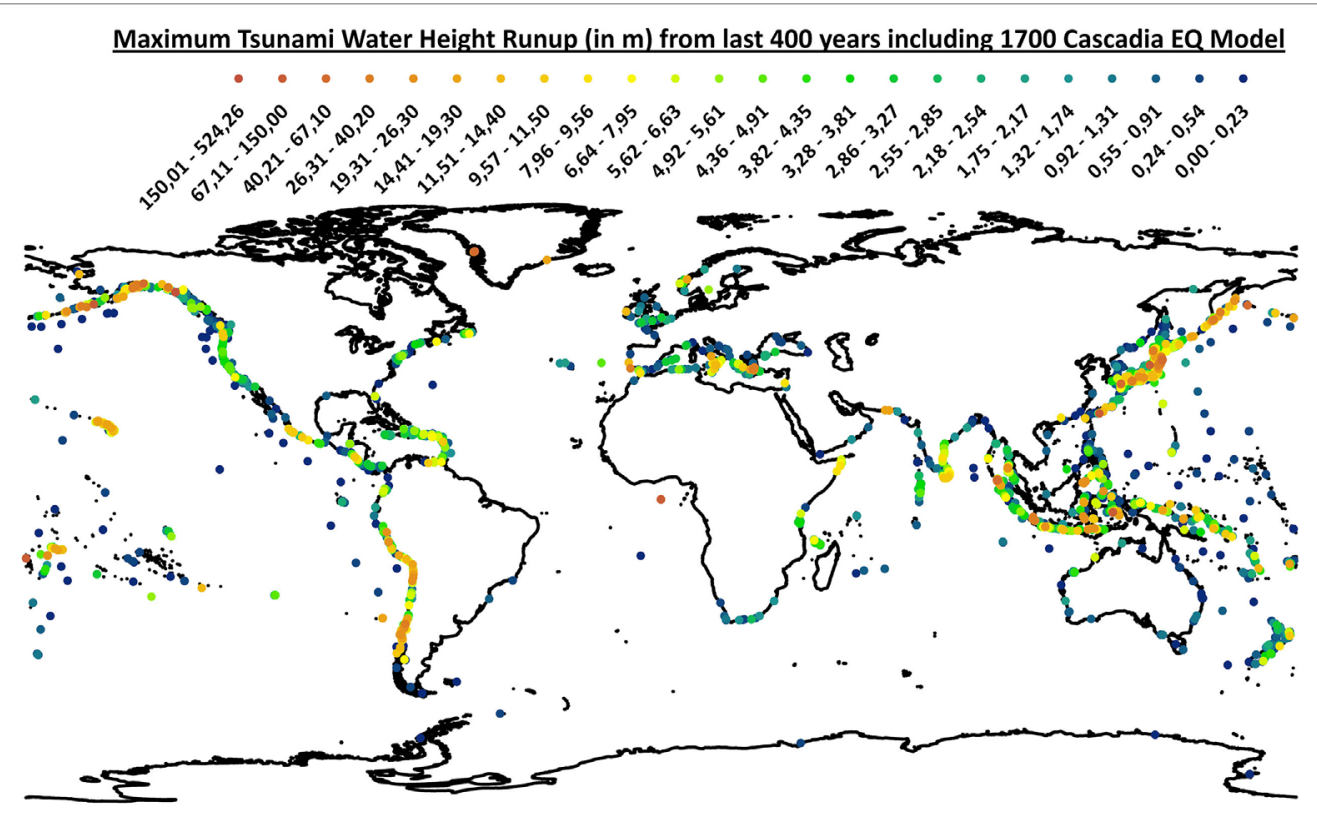

FIGURE 2 | Maximum tsunami water height runup (in meters) from the last 400 years from a combination of modeling and National Geophysical Data Center, including a 1700 Cascadia EQ Model. 
California, Japan, New Zealand, and Australia as shown by the proportion of brown color (wooden stock) in Figure 3 of each nation globally.

Flooding in terms of dam breaks and reservoir failures can cause major damage and also be a huge hazard to populations. Generally, large dams have been built to withstand earthquake forces, but the simple lateral shaking can sometimes cause massive failures of natural or man-made systems, such as seen in the 1933 Diexi earthquake (Shi-zhong, 2010) (Table 6). Landslides can also sometimes cause blockages to rivers, forming quake lakes which can then, if unstabilized, unleash huge flooding on settlements downstream. Although there have not been many instances, flow-on disasters such as a flood where an earthquake

TABLE 5 | The effect of larger fire events since 1900.

\begin{tabular}{|c|c|c|}
\hline Date and location & $\begin{array}{l}\text { Magnitude of } \\
\text { event }\end{array}$ & Fatalities and/or economic losses ${ }^{a}$ \\
\hline 1923 Great Kanto & Mw 7.9 & $\begin{array}{l}92,190 \text { deaths }(87 \%) ; 2 / 3 \text { of the damage } \\
(\$ 40 b n+\mathrm{CPI} \text { adjusted); ca. } \$ 220 \mathrm{bn} \\
\mathrm{HNDECI}\end{array}$ \\
\hline 1906 San Francisco & Mw 7.9 & $\begin{array}{l}\text { 1,800 deaths ( } 60 \%) ; \text { ca. } 5 / 6 \text { of damage } \\
\text { (ca. } \$ 10 \mathrm{bn} \mathrm{CPI} \text { adjusted); } \$ 50.6 \mathrm{bn} \\
\mathrm{HNDECI}\end{array}$ \\
\hline $\begin{array}{l}1995 \text { Great Hanshin, } \\
\text { Aawji, Kobe }\end{array}$ & Mw 6.9 & 570 deaths $(9 \%)$ \\
\hline 1948 Fukui & Mw 7 & 513 deaths (10\%) \\
\hline 1925 Dali & Ms 7 & 400 deaths $(7 \%)$ \\
\hline 1906 Valparaiso & Mw 8.5 & 388 deaths (10\%) \\
\hline
\end{tabular}

${ }^{a}$ Median estimate from literature. occurs simultaneously can have major cascading impacts. In Figure 4,623 of the 6,862 dams are expected to have a shaking hazard of $0.3 \mathrm{~g}$ within 475 years (shown in orange and red). Of these, over half (333 out of 623) are over 45 years old, indicating the need for reassessment of these dams. Flooding also caused many fatalities in the 1949 Ambato/Pelileo earthquake in Ecuador. Figure 4 depicts the earthquake hazard of 6,800+ dams and reservoirs worldwide.

Surface rupture is simply the visible displacement along the fault which causes surface cracks or surface slip to appear. This was seen visually in the 2008 Sichuan earthquake, where much damage was due to fault rupture. General laws have been that fault rupture occurs in earthquakes with a magnitude greater than 6. Surface fault rupture zones have not caused much damage historically, however, as the known fault zones are generally not built upon in locations such as the Western USA, and also the rupture surface is generally not very wide, thus minimizing the chance for damage. In the recent Kaikoura 2016 event, a 10-m displacement occurred through an existing house causing major damage but no fatalities.

Despite Hollywood film attempts to pitch fault rupture as a major cause of destruction in earthquakes, fault rupture has not recorded many observed fatalities.

\section{AGGREGATED LOSSES DUE TO SECONDARY EFFECTS}

A review of earthquake fatalities over time gives the first insight into the fatality risk of earthquakes. Using the CATDAT Damaging

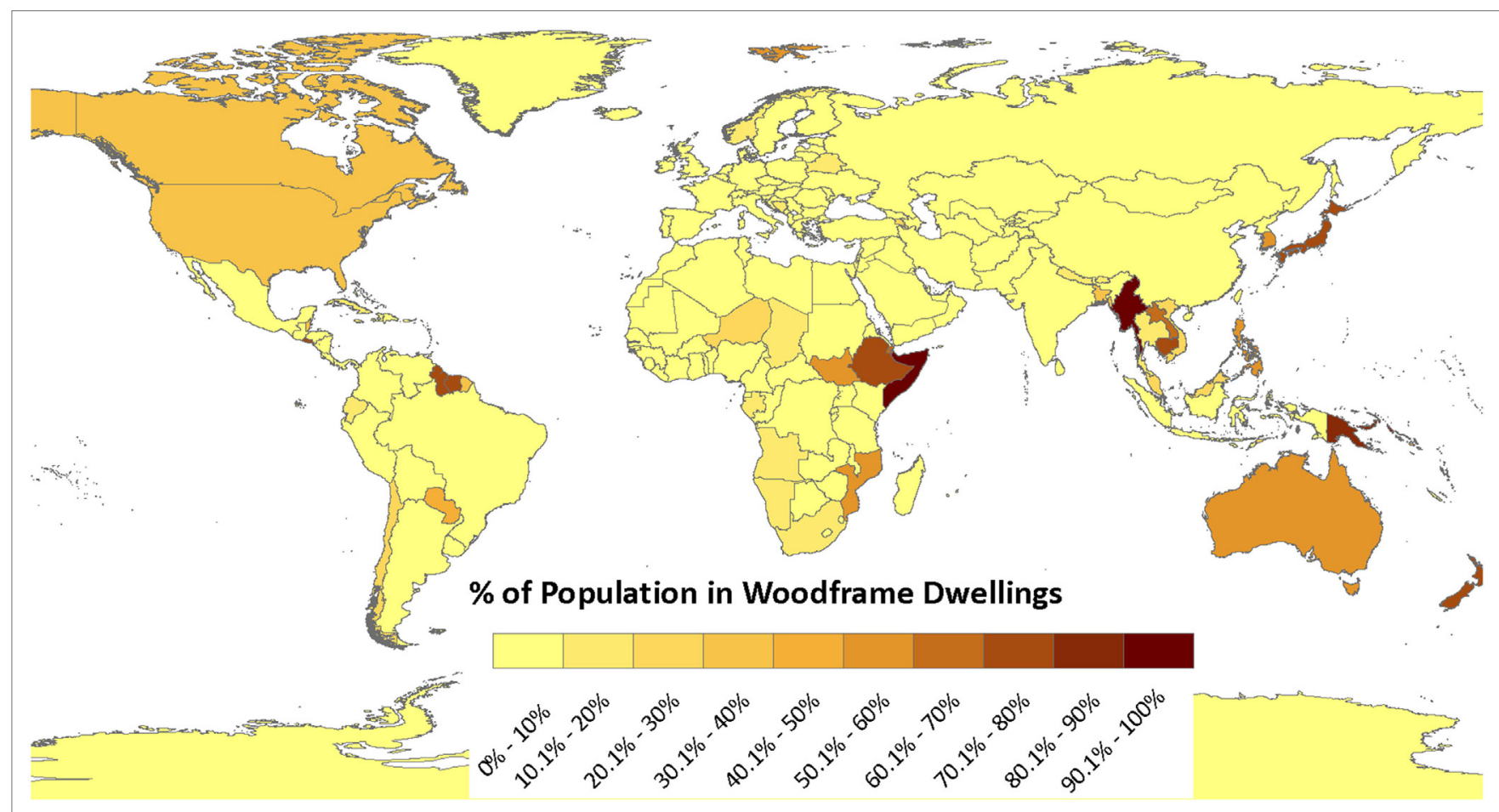

FIGURE 3 | The percentage of population in wood-frame buildings globally for each country as created as part of Daniell et al. (2011c). 
Earthquakes Database (Daniell et al., 2011a) which contains ca. 16,000 damaging earthquake events through time, the earthquake fatalities are examined and trends built. For this paper, we focus on 1900 onward. The reader is instructed to examine Daniell et al. (2011a) and Slingsby et al. (2011) for details as to the structure and collection of the database.

Over the period from 2003 to 2016, the CATDAT Damaging Earthquakes Database has been collected from many sources globally. In-depth analysis has been undertaken to disaggregate fatalities from earthquakes into the different causes of the fatality, whether it be from direct structural collapse or secondary effects such as tsunami, landslide or otherwise from 1900 to 2016, and 9,900+ damaging earthquakes with economic losses since 1900. Earthquakes have caused over 2.3 million fatalities since 1900 in 2,233 fatal events, with many of these coming through large, infrequent events. In fact, since 1900, 59\% of these fatalities have occurred in just 10 events. In fact, the top 100 events account for 93.25\% of fatalities as seen in Figure 5.

A list of the top 10 fatal earthquakes since 1900 are included with the approximate breakdown of secondary and primary effects as well as an attempt as to the number of fatalities due to all engineered structures, showing the need for sensitive design for not only shaking but also for secondary effects in Table 7.

Many of these fatalities were as a result of secondary effects such as tsunami, fire, and landslide as can be seen in the above table. However, most were due to non-engineered collapse of masonry buildings (the $\%$ of engineered estimated structures is

TABLE 6 | The effect of larger dam/blockage failures since 1900.

\begin{tabular}{lll}
\hline Date and location & $\begin{array}{l}\text { Magnitude of } \\
\text { event }\end{array}$ & Fatalities and/or economic losses \\
\hline 1933 Diexi & Mw 7.3 & $\begin{array}{l}\text { Ca. 4,700 deaths via collapsed dam } \\
\text { 1949 Pelileo }\end{array}$ \\
2008 Sichuan & Mw 7.8 & $\begin{array}{l}\text { Ca. 3,000 deaths via blocked channel } \\
\text { Many quake lakes produced, mass } \\
\text { evacuations }\end{array}$
\end{tabular}

shown in the table of top 10 earthquakes). It has been found that over $57 \%$ of deaths have occurred in masonry buildings either by falling structural members, roof collapse, or falling debris. An additional 8.5\% have died in concrete buildings and 3\% in timber buildings. In total, approximately $71 \%$ of fatalities have occurred due to direct earthquake shaking and $29 \%$ to other earthquake secondary effects as shown in Figure 6. The database is a dynamic entity and continues to change as further reanalysis of past events takes place, including separating heart attack deaths and non-structural deaths.

A detailed study of all 9,920 damaging earthquakes from 1 January 1900 to 31 December 2016 has been undertaken by examining the original sources, descriptions, and expert opinion (where experts from various entities are asked as to their opinions post-disaster and their estimates weighted) where exact dollar amount losses with regard to disaggregation have been calculated. Figure 7 shows results for direct losses and total economic losses from earthquakes. Approximately $70 \%$ of direct economic losses have come from direct earthquake effects, whereas $30 \%$ have occurred due to secondary effects of earthquakes. For total economic losses, taking into account the indirect losses, this percentage increases to $38 \%$. This has many implications for our earthquake research. The focus on just shaking losses should be changed to one of holistic strategies for shaking and secondary effects losses.

Landslides can be seen to cause over 5\% of economic losses, and this has only been low due to the relatively low populations living worldwide in mountainous areas exposed to earthquakes since 1900. China has experienced major losses through the 1920 Haiyuan and 2008 Sichuan earthquakes. 1949 Khait and 1970 Ancash were also major landslide-bearing earthquakes causing major economic losses to their respective countries. The 2011 Tohoku and 2004 Indian Ocean earthquakes have both brought about much of the economic losses due to tsunami in recent years; however, many tsunami-bearing earthquakes have caused much damage, such as 1960 Chile and 1964 Alaska with over 10\% of

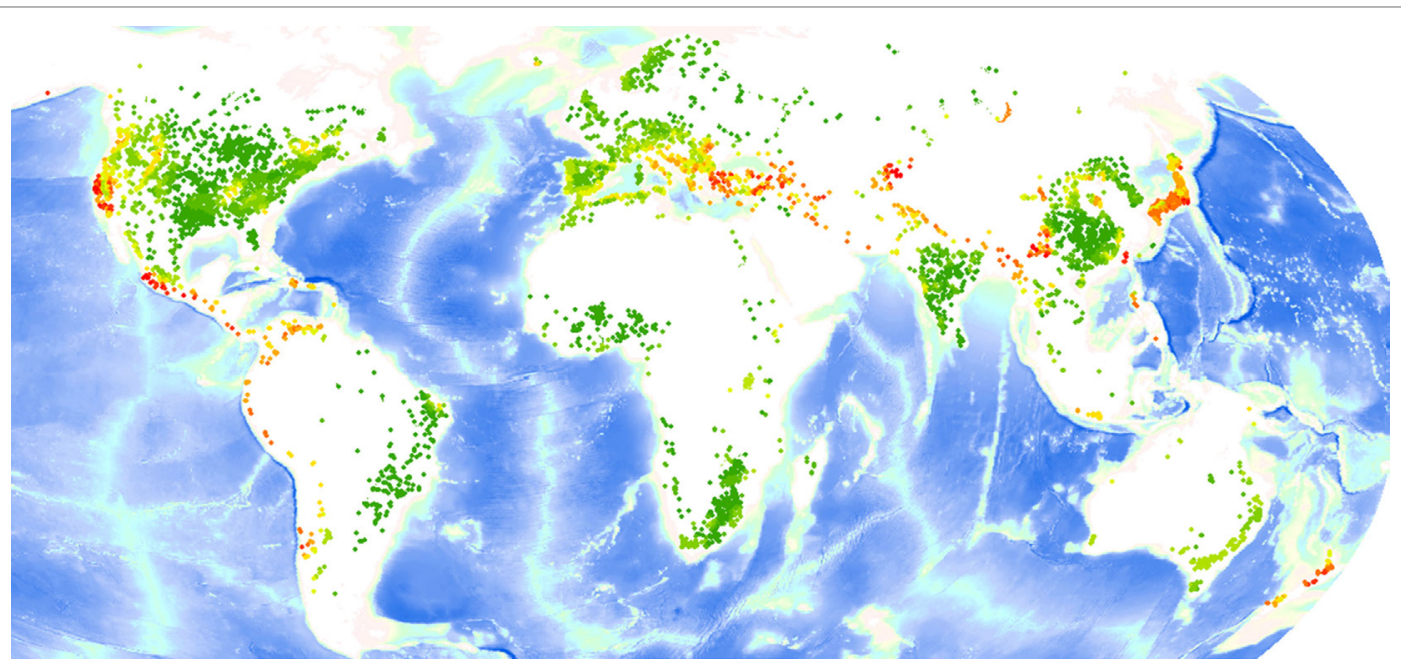

FIGURE 4 | The earthquake hazard of the $6,800+$ dams and reservoirs worldwide from the GRanD database [in comparison to the GSHAP (10\% exceedance in 50 years)] 


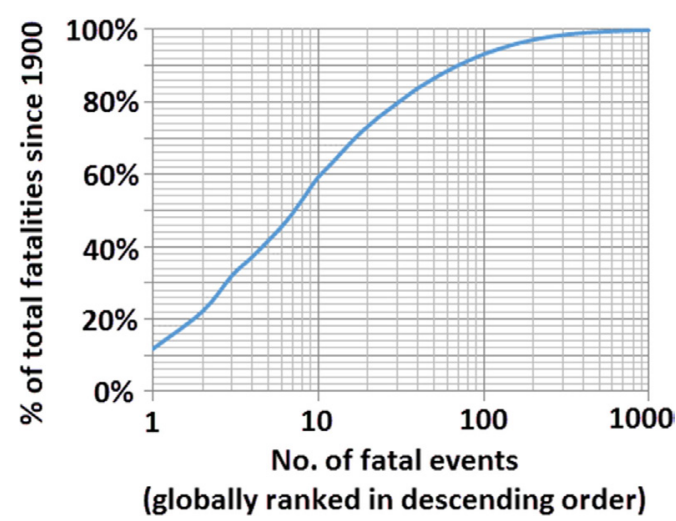

FIGURE 5 | No. of fatalities (cumulative) globally ranked in descending order from largest to smallest event.

TABLE 7 | The top 10 earthquakes in terms of fatalities.

\begin{tabular}{lrcrr}
\hline Earthquake & Median & \%Eng & Prim. (\%) & Sec. (\%) \\
\hline 1920 Haiyuan & 273,400 & $<1$ & 50.0 & 50.0 \\
1976 Tangshan & 242,400 & 20 & 100.0 & 0.0 \\
2004 Ind. Ocean & 228,100 & $<5$ & 0.5 & 99.5 \\
1923 Great Kanto & 105,385 & $<5$ & 10.5 & 89.5 \\
1948 Aschgabat & 100,000 & $50^{a}$ & 100.0 & 0.0 \\
2008 Sichuan & 88,300 & $<30$ & 70.0 & 30.0 \\
2005 Kashmir & 87,400 & $<5$ & 69.7 & 30.3 \\
1908 Messina & 86,000 & $<1$ & 97.0 & 3.0 \\
2010 Haiti & 80,000 & $<10$ & 100.0 & 0.0 \\
1970 Ancash & 66,800 & $<1$ & 60.0 & 40.0 \\
Total & 1357,785 & $<10$ & 817,533 & 540,252
\end{tabular}

a Based on an early Soviet code. total losses due to tsunami, and additional NaTech losses via the power plant disaster in Tohoku.

\section{CASE STUDIES}

Two case studies are discussed to examine the disaggregation process, values, and uncertainties associated with the estimates of secondary effect losses.

\section{Case Study 1: Tohoku}

\section{Earthquake-Disaggregating the Fatalities}

Within 50 separate articles produced after Tohoku (Daniell and Vervaeck, 2011), each spanning a few days, and associated situation reports in conjunction with http://earthquake-report. com, a detailed update of damage data, economic losses, and social impacts (homelessness, injuries, deaths) of the Fukushima disaster, including translations of the FDMA ${ }^{2}$ reports, GIS data, and collated statistical data, was given to the public and many companies. Much work was also done to analyze the sectoral losses and to disaggregate the tsunami, earthquake, and power plant losses using information from each municipality to create non-coastal vs. coastal losses. In addition, historical Japanese damage ratio data and tsunami inundation maps were used to further disaggregate losses in the coastal municipalities and plot the 1.2 million buildings damaged.

The inundation map vs. the number of buildings in each municipality allowed the number of destroyed buildings to be

${ }^{2}$ http://www.fdma.go.jp/bn/higaihou/pdf/jishin/155.pdf.

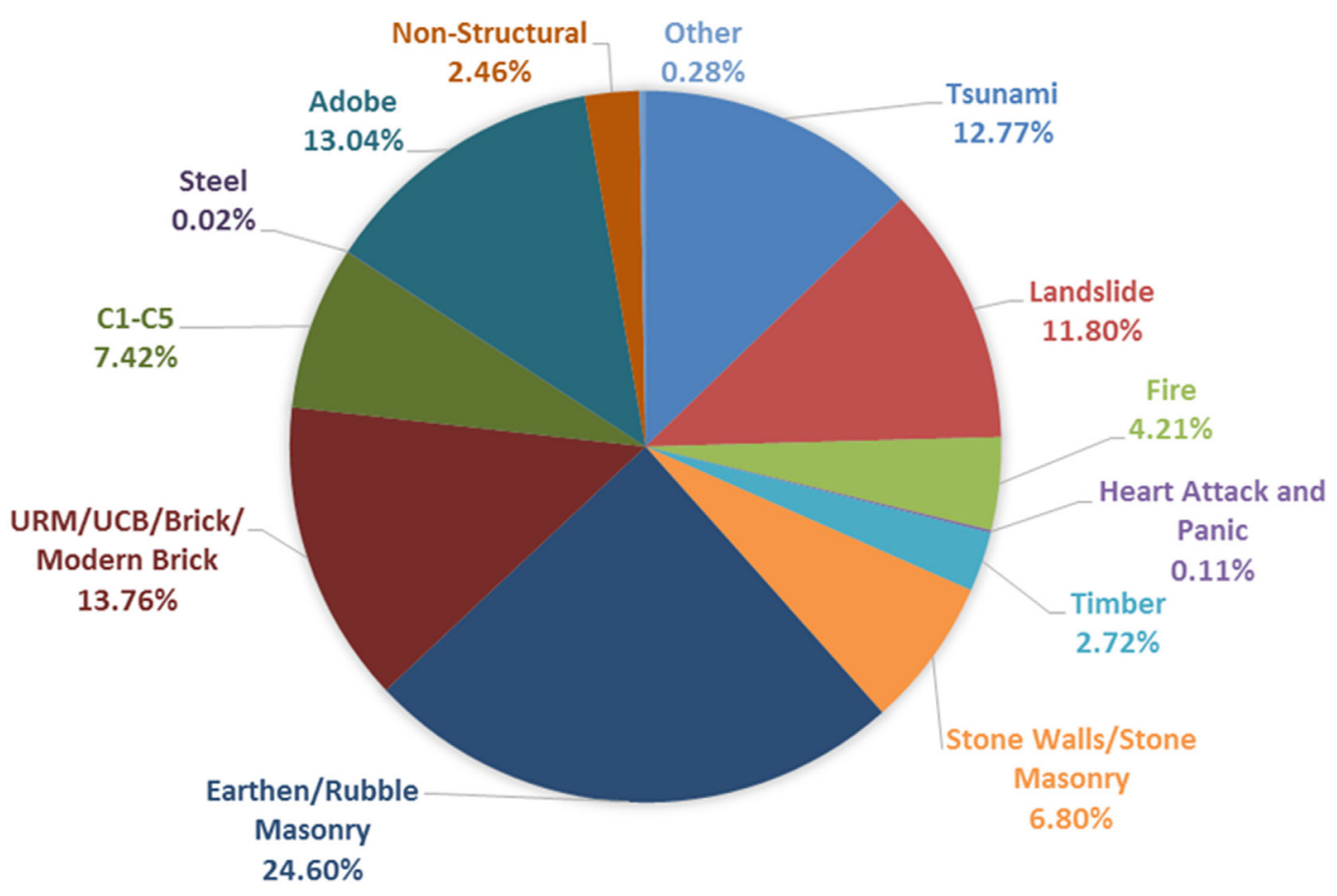

FIGURE 6 | The upper and lower bound death toll estimate of earthquakes in global literature compared to the median CATDAT death toll, current as of December 31, 2016. 


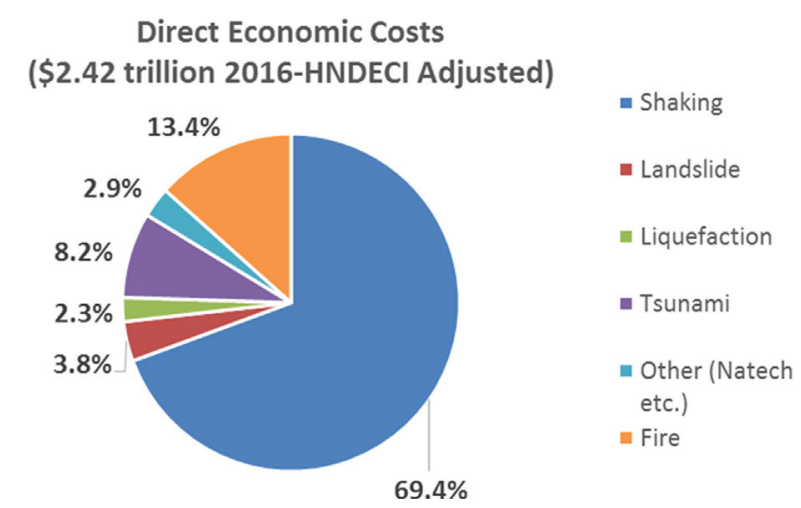

\section{Total Economic Costs \\ (\$3.41 trillion 2016-HNDECl Adjusted)}

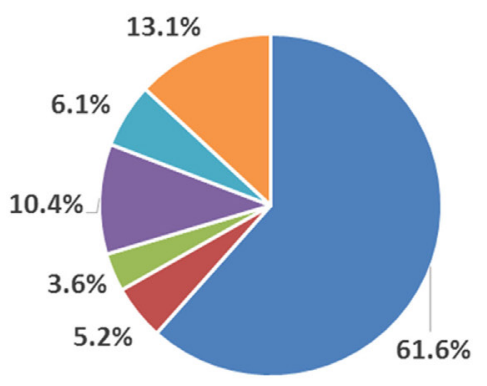

FIGURE 7 | Disaggregation of shaking and secondary effects economic costs from 9,920 earthquakes from 1900 to $2016-$ left: direct economic costs; right: total economic costs.

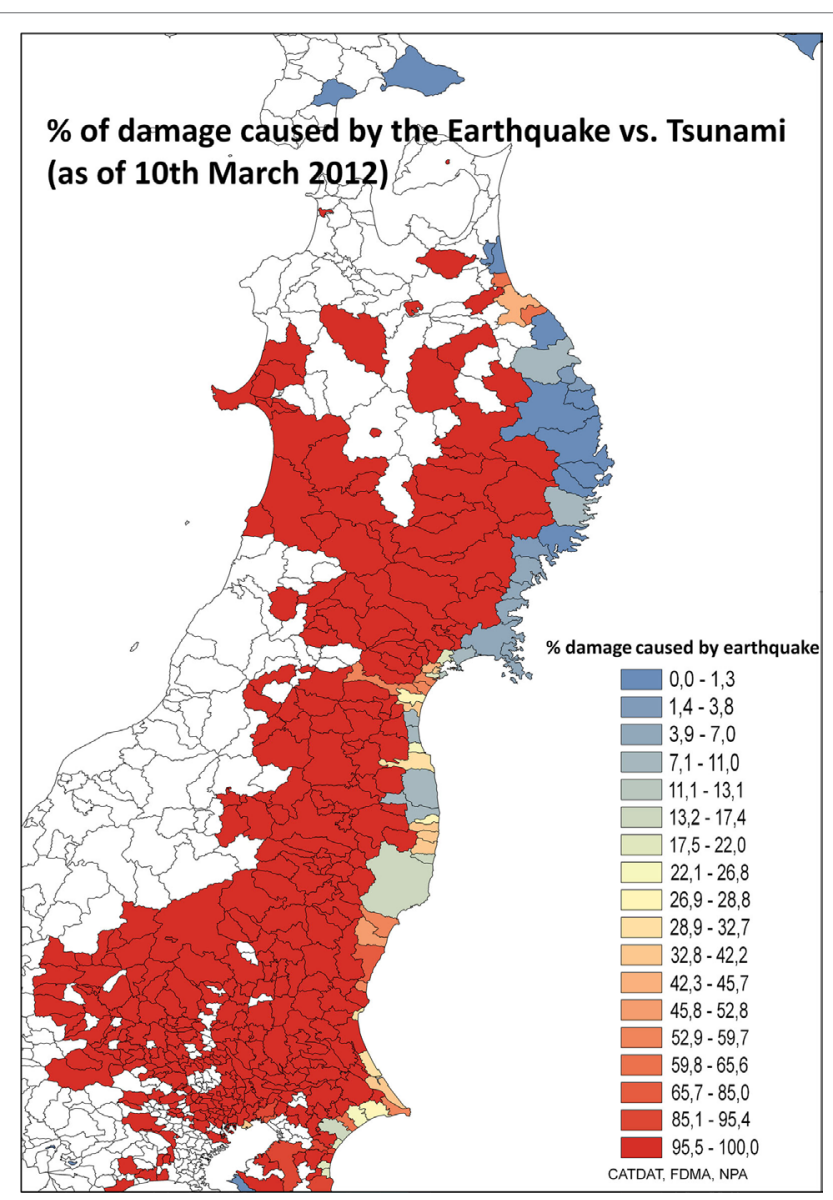

FIGURE 8 | The disaggregated earthquake versus tsunami damage in each municipality (dark red $=100 \%$ damage caused by earthquake, dark blue $=100 \%$ damage caused by tsunami, and yellow $=50 \%$ damage via earthquake, $50 \%$ via tsunami).

calculated, as shown in Figure 8, showing that the impact in Sendai itself was less than first expected via the tsunami but there was a higher percentage loss due to the earthquake (Table 8). The functions of were used to produce the damage functions that
TABLE 8 | Building damage statistics for the 2011 Tohoku EQ disaggregated for tsunami and earthquake.

\begin{tabular}{|c|c|c|c|}
\hline Buildings & Destroyed & Partially destroyed & Partially damaged \\
\hline Tsunami & $98,697-112,402$ & $78,294-158,636$ & $31,225-95,254$ \\
\hline Earthquake & $13,721-28,147$ & $113,277-194,367$ & $705,198-771,616$ \\
\hline
\end{tabular}

were then utilized. The normalization of various parameters of historical earthquakes to 2011 conditions, using population and dwelling changes, vulnerability changes, and community wealth changes as per Daniell and Love (2010), were also checked.

An additional 35,466 buildings were in the towns and cities within the exclusion zone of the Fukushima I and II nuclear sites. The best estimate of damage to buildings from Daniell and Vervaeck (2011) and then Khazai et al. (2011) from each of the three events was the earthquake (49\%), tsunami (39\%), and nuclear disaster $(12 \%)$. With total direct losses, this reduced to earthquake (44\%), tsunami (38\%), and nuclear disaster (18\%).

There were around 30,000 shaking deaths in the CATDAT Damaging Earthquakes Database from 1900 to 2010 before the 2011 Tohoku Earthquake in Japan. Of these, most occurred in 1923 Great Kanto (11,000 shaking deaths), 1927 Tango $(3,110)$, 1943 Tottori (1,325), 1945 Mikawa (2,306), 1948 Fukui (4,618), and 1995 Kobe $(4,823)$.

The use of the seismic code index, other social vulnerability and building practice indicators, and other normalization strategies ensured that the casualty model was calibrated to today's conditions. It would be inaccurate to simply use casualties from a 1970 earthquake, as $80 \%$ of the Japanese building stock has been built since; thus, the Human Development Index shift in the fatality function calculates better the fatality change over time.

A comparison of results from various empirical Japanese casualty estimation models is shown in Table 9 for the M9 earthquake, using a basis of 13,000-26,000 destroyed buildings and 74,000-126,000 half-destroyed buildings as a result of the earthquake. This is in comparison to the $92,000+$ buildings destroyed and 78,000+ houses partially destroyed by the tsunami. MMI >7-7.5 townships were used for the regression methods of Ye and Okada (2001). 
TABLE 9 | Casualty range loss estimates from selected casualty models for the 2011 Tohoku EQ for earthquake shaking deaths.

\begin{tabular}{lrrr}
\hline Casualty model & Lower & Median $^{\text {a }}$ & Upper \\
\hline Kawasumi (1954) & 2,187 & 3,410 & 5,567 \\
Tokyo Metropolitan Government (1978) & 1,716 & 2,334 & 3,132 \\
Saitama Prefecture (1982) & 35 & 39 & 43 \\
Onta et al. (1983) & 210 & 288 & 409 \\
Disaster Prevention Council and Tokyo & 229 & 291 & 360 \\
Metropolitan Government (1985) & & & \\
Ohta and Goto (1985) & 95 & 120 & 156 \\
Osaka Prefecture (1997) & 781 & 1,098 & 1,601 \\
Ikeda and Nakabayashi (1996) & 729 & 1,026 & 1,496 \\
Ye et al. (2001) & 104 & 163 & 244 \\
USGS PAGER v12-USGS (2011, 2013) & 100 & 1,030 & 10,000 \\
WAPMERR QLARM-World Agency of Planetary & 0 & Unk. & 1,000 \\
Monitoring and Earthquake Risk Reduction (2013) & & & \\
CATDAT EQLIPSE-Q-Daniell and Wenzel (2014) & 291 & 673 & 1,340 \\
CATDAT EQLIPSE-R-Daniell et al. (2011b) & 133 & 420 & 781 \\
Total shaking deaths from Japan & 110 & $190-230$ & 250 \\
\hline
\end{tabular}

aMedian estimate equals 18,207 destroyed houses, 100,414 partially destroyed.
It is still unknown how many victims have died directly due to the earthquake action. A total of 14,308 were reported in March 2012 to have drowned, 667 were crushed or died of internal injuries (mainly tsunami), and 145 perished via burns. It will never be known how many died due to the earthquake, as separated from the tsunami; however, the autopsies give us an indication that we can expect that about $1.0 \%$ of the $4.4 \%$ crushed were probably in earthquake collapsed houses.

In addition, we can assume a proportion of the remaining $2 \%$ that were unknown were also earthquake-related (a high value of $10 \%$ could be assumed). This would leave about $1.2 \%$ or about 158. When extrapolating for the final 3,000 deaths that were not stress or chronic disease related, then the total is approximately 220. This value corresponded quite well to the 137 non-tsunami impacted deaths that were recorded in the non-coastal areas when splitting the fatalities between coastal and non-coastal municipalities. Some of the non-coastal deaths, however, were due to heart attack, fire, or landslide. Thus, only around 110

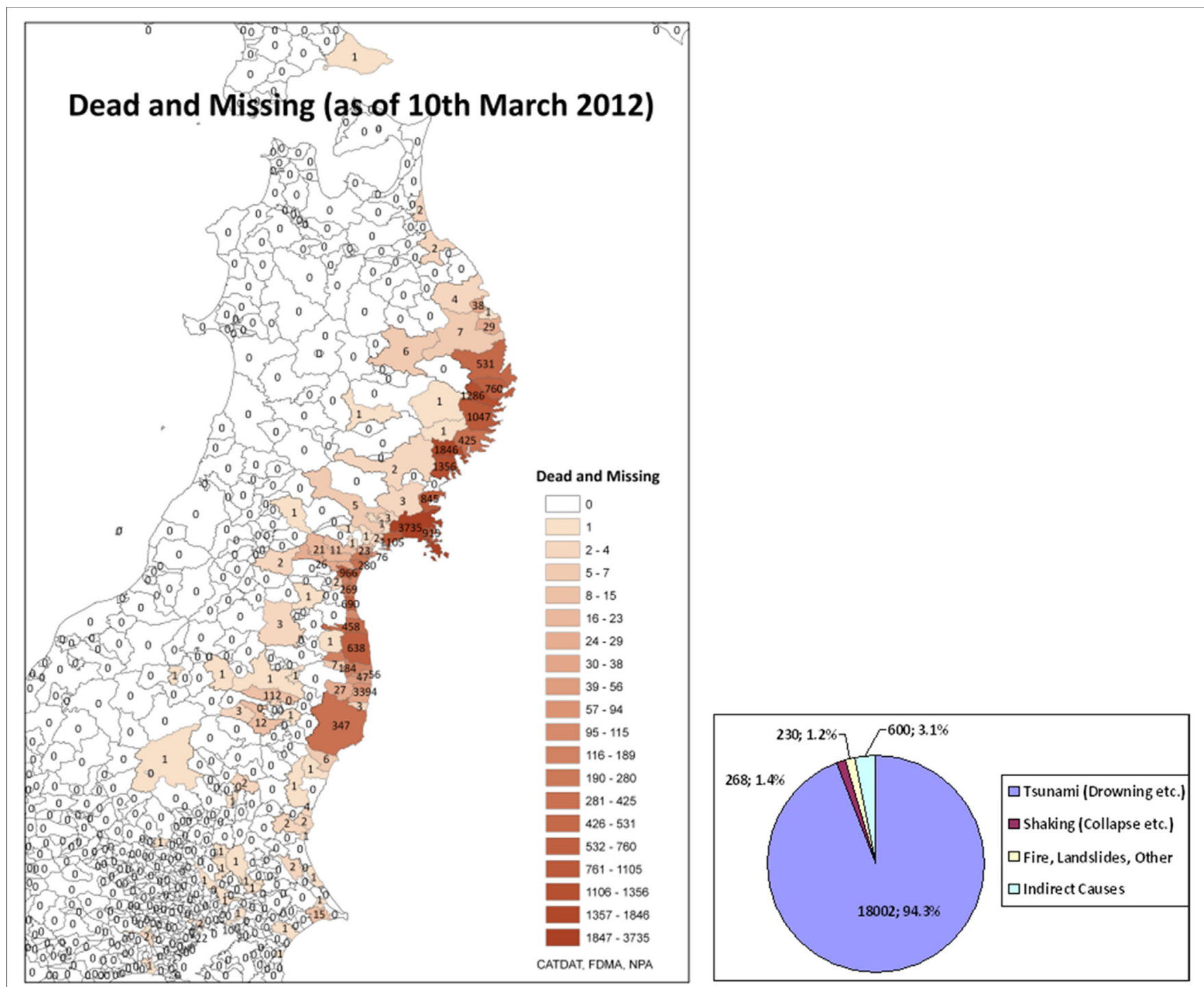

FIGURE 9 | Left: deaths in municipalities as collected from FDMA, National Police Agency Japan (NPA) (2011), and additional Japanese sources; right: the disaggregated deaths as of 11 March 2016 (5 years after). Of the 230 shaking deaths, only around 110 have been confirmed. 
TABLE 10 | Casualty and economic loss information for the 1960 earthquake and tsunami event in Chile from various sources.

\begin{tabular}{|c|c|c|c|}
\hline Source & Earthquake effects & Tsunami effects & Both \\
\hline $\begin{array}{l}\text { La Cruz del Sur, 28.05.1960 via Director- } \\
\text { General of Police }\end{array}$ & & & 962 dead, 1,410 missing \\
\hline Flores (1960) & 5,000 deaths & & 5,000 deaths \\
\hline U.S. Coast and Geodetic Survey (1962) & & 231 deaths overseas & $\begin{array}{l}\text { 2,000 deaths in Chile, } 231 \text { deaths in other locations, } \\
\$ 550 \mathrm{~m} \text { in Chile, } \$ 75 \mathrm{~m} \text { Hawaii, } \$ 50 \mathrm{~m} \text { Japan (1960) }\end{array}$ \\
\hline Instituto Hidrografico de la Armada (1982) & & & 2,000 deaths, $\$ 1,000 m(1960)$ \\
\hline Lander et al. (1993) & & 1,263 deaths, $\$ 75 \mathrm{~m}$ & \\
\hline $\begin{array}{l}\text { Soloviev and Go (1975), translated } 1984 \\
\text { through lida et al. (1967) }\end{array}$ & & $\begin{array}{l}1,000 \text { deaths in Chile, } 60 \text { in Hawaii, } \\
200 \text { in Japan }\end{array}$ & 1,000 deaths in Chile \\
\hline MunichRe (1998) and Berz (1988) & & & 3,000 deaths, $\$ 800-880 m(1960)$ \\
\hline Saint-Amand (1961) & 500 deaths & 1,000 deaths & 1,500 deaths, $\$ 417 \mathrm{~m}$ \\
\hline Rothe (1969) & & & $\begin{array}{l}660 \text { deaths and } 717 \text { missing (Tazieff, 1962), \$550m } \\
\text { (1960), } 185 \text { deaths (Japan), } 61 \text { deaths (Hawaii) }\end{array}$ \\
\hline Lockridge (1985) & & $\begin{array}{l}\text { Chiloe Is. (200), Valdivia (130) as } \\
\text { part of 1,000 in Chile }\end{array}$ & $\begin{array}{l}\text { 1,000 deaths (all of Chile), } 61 \text { deaths (Hawaii), } 199 \\
\text { deaths (Japan) }\end{array}$ \\
\hline Barrientos and Ward (1990) & & & $\$ 500-700 m$ in Chile \\
\hline EM-DAT & 6,000 deaths, $\$ 550 \mathrm{mn}(1960)$ & & \\
\hline Lazo Hinrichs (2008) & $\begin{array}{l}\$ 300 \mathrm{~b} \text { Pesos (houses) } \$ 50 \mathrm{~b} \mathrm{CL} \\
\text { CLP agriculture and industry, } \$ 3\end{array}$ & $\begin{array}{l}\text { P public and private buildings, } \$ 80 b \\
\text { Ob CLP transport, } \$ 20 b \text { CLP various }\end{array}$ & 2,500 (Official)-5,000 deaths (Chile) \\
\hline
\end{tabular}

can be certain as due to shaking. It is likely that there are exact numbers available.

As of December 2016, the FDMA reported that 19,475 were killed and 2,587 were missing from the 11 March 2011 event with at least 3,440 deaths of these due to indirect causes. These values differ from the Fire Disaster Management Agency Japan (2011), given the inclusion of "additional related deaths" which have totaled around 2,400 as of 2013, and 600 at the time of the diagram in March 2012, as shown in Figure 9, slightly less than the percentage reported in the Kobe earthquake. With the removal of these, the total deaths from FDMA are also about 18,500. Around 110-220 deaths would be earthquake-collapse related. About 250 would be related to other causes such as fire, landslides, etc. Around $94 \%$ of deaths were tsunami related.

This means that the most reasonable estimates were derived from Ye et al. (2001). PAGER, QLARM, and this study (EQLIPSE-Q and R) all performed reasonably well, given the uncertainty of the number of shaking deaths 5 months after the event. The Tohoku earthquake in 2011 provided a situation where the size of the event was outside the expected values. Historical GMPEs and IPEs used for historical Japanese earthquakes were outside the magnitude range $(\mathrm{Mw}=9.0)$. This made difficulties for the modeling of intensities and damage. The quality of data in terms of intensities and ground motion measurements made it possible to create loss estimates in the correct order of magnitude.

\section{Case Study 2: 1960 Chile Tsunami}

The 1960 Chile earthquake and tsunami sequence on 21 and 22 of May, 1960 caused shaking damage as well as tsunami and landslide effects. By far, the most devastating component was the shaking damage; however, the earthquake and tsunami are interesting for the fact of the range of uncertainties in the literature and the fact that the tsunami likely caused more fatalities than shaking.

The 1960 Chile earthquake caused somewhere between 1,600 and 3,500 deaths, with 1,655 or 2,000 or 2,500 the most accepted number. Of these, at least 1,000 deaths were tsunami-based, if not in the order of 1,500 . The tsunami to earthquake death ratio was likely 2 to 1 . The following shows the uncertainties within numbers in literature.

Estimates of up to 7,231 deaths exist in literature (Table 10), possibly being an error (EM-DAT) and as low as 490, with economic losses split in a ratio of $\$ 550 \mathrm{mn}$ for shaking vs. $\$ 50 \mathrm{~m}$ for tsunami, with 6,000 deaths attributable to the earthquake, and 1,231 to tsunami originally. This has since been changed to just the earthquake shaking losses. Talley Jr. and Cloud (1962) gave an estimate of 2,000 deaths due to earthquake and 231 due to tsunami, whereas Saint-Amand (1961) gives 1,000 due to tsunami and 500 due to earthquake. Interestingly, Flores (1960) gives a value for the foreshock of 500 deaths on the 21st May and attributes then 5,000 deaths to the earthquake on the 22nd May. Preferred estimates for disasters are generally local, but even these differ from 500 to 5,700 deaths.

From the tsunami, these estimates from the entire Peru-Chile coastline ranged from 330 to 2,000 people with somewhere between 200 and 800 deaths on Isla Chiloe (which was the hardest hit location). The work of Mancilla and Mardones (2010) also mimics the uncertainty in numbers of deaths due to the tsunami and earthquake.

For exploratory reasons, the 1960 Chile tsunami, also called Valdivia tsunami has been selected. It occurred on the southern 


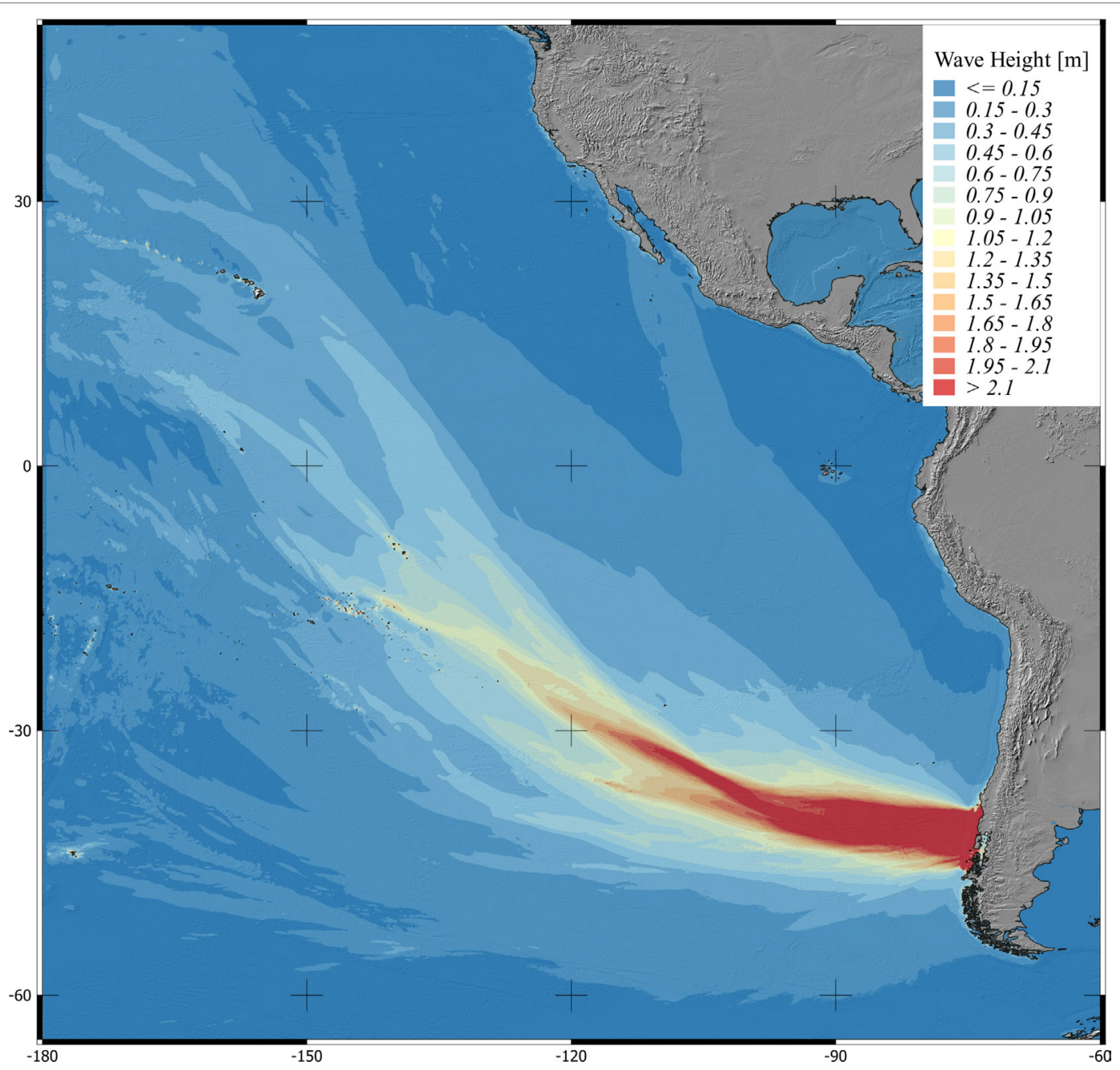

FIGURE 10 | The modeling of the reanalyzed 1960 tsunami event and the effects on Chile as well as Hawaii.

tip on of the most seismically active regions in the world, the Andean subduction zone of the Nazca plate offshore Chile (Schaefer et al., 2015). With a moment magnitude of about 9.5, it is the strongest earthquake ever recorded. Unfortunately, in 1960, the record of the tsunami is limited both for wave propagation and inundation; thus, reconstruction of this event is ambiguous.

For numerical modeling, the tsupy methodology of Schaefer and Wenzel (2017) is used. Here, the non-linear shallow water wave equations are used in a parallelized framework to compute propagation and inundation patterns on a moderate resolution. The tsunami source is modeled using a slip distribution considering the methodologies of Mai and Beroza (2002) and (Goda et al., 2014) representing the $3 \mathrm{D}$ distribution of movement along the fault plane of an earthquake rupture, which is afterward projected to a surface deformation using the equations of Okada (1985). It has been shown that the tsunami impact and inundation pattern along coastlines close to the epicenter is highly dependent on the slip distribution. Differences in inundation heights can reach well beyond a factor of two just by a variation of the slip distribution.

For this test case, the slip distribution of Fuji and Satake (2013) is considered, which has been resolved inversely from geodetic and observed tsunami data. As for recent event, inversely resolved distributions are not unique, e.g., for Japan where a tenfold of possible results could be considered. The tsunami is simulated numerically using two regular grids with resolutions of $1 \mathrm{~km}$ and $90 \mathrm{~m}$ as shown in Figure 10. The 1-km grid is used to calculate the long-distance travel of the tsunami, while the 90-m grid, which consists of the region between Concepcion and Valdivia, is used to compute the inundation. It is hoped that a reanalysis using this type of methodology, mimicking the historical observed tsunami inundations at various points; as well as adding the 1960 capital stock and building typologies at the time of the event may allow for better information on this event to be gained to better split the "estimated" secondary effect deaths and economic losses. 


\section{DISCUSSION AND CONCLUDING REMARKS}

The role of secondary effects of earthquakes for damage and loss has been shown as highly relevant through history. Although somewhere between 60 and $75 \%$ of economic losses as well as deaths have been due to shaking effects, between 25 and $40 \%$ of these impacts have been due to secondary effects in the form of tsunamis, landslides, liquefaction, fire, and other less common types.

For fatalities, this study agrees well with the original work of Coburn and Spence (1992) that showed for 1,100 fatal earthquakes from 1900 to 1990 around $76 \%$ of fatalities were from shaking and 24\% from secondary effects. Marano et al. (2010) in PAGER on 749 fatal earthquakes from September 1968 to June 2008 demonstrated that $25 \%$ of fatalities from earthquakes were due to secondary effects of earthquakes (tsunami, landslide, fire, liquefaction). A total of 913 fatal earthquakes were recorded in the CATDAT database in the same time period from 1968 to 2008. Both studies are much lower than the study of Bird and Bommer (2004) on 50 earthquakes from 1980 to 2003, showing that $90 \%$ of earthquake deaths are due to shaking. It should be noted that deaths due to volcanic effects have simply been removed from the earthquake records. The 2010 version of the CATDAT Damaging Volcanoes Database shows the various effects of volcano related earthquakes such as the 2002 eruption episode of Lake Kivu, and the 1914 Sakurajima earthquakes (Daniell, 2011).

It has been seen that there is much uncertainty in numbers post-disaster and depending on the source used there are many different opinions as to the influence of secondary effects in terms of the absolute numbers of their impact as seen by the number of sources in the Chile 1960 earthquake. In newer events, better reporting within countries with the advent of Desinventar ${ }^{3}$ and

${ }^{3}$ www.desinventar.org.

\section{REFERENCES}

Allstadt, K., Hearne, M., Nowicki, M. A., Thompson, A., Wald, E. M., and Zhu, D. J. J. (2017). Integrating Landslide and Liquefaction Hazard and Loss Estimates with Existing USGS Real-Time Earthquake Information Products, 16th World Conference on Earthquake Engineering. Santiago, Chile.

Barrientos, S. E., and Ward, S. N. (1990). The 1960 Chile earthquake: inversion for slip distribution from surface deformation. Geophys. J. Int. 103, 589-598. doi:10.1111/j.1365-246X.1990.tb05673.x

Beck, C. (2009). Late quaternary lacustrine paleo-seismic archives in NorthWestern Alps: examples of earthquake-origin assessment of sedimentary disturbances. Earth Sci. Rev. 96, 327-344. doi:10.1016/j.earscirev.2009.07.005

Berz, G. (1988). List of major natural disasters, 1960-1987. Nat. Hazards 1, 97-99. doi:10.1007/BF00168223

Bird, J. F., and Bommer, J. J. (2004). Earthquake losses due to ground failure. Eng. Geol. 75, 147-179. doi:10.1016/j.enggeo.2004.05.006

Bommer, J. J., and Rodriguez, C. E. (2002). Earthquake-induced landslides in Central America. Eng. Geol. 63, 189-220. doi:10.1016/S0013-7952(01)00081-3

Cetin, K. O., Der Kiureghian, A., and Seed, R. B. (2002). Probabilistic models for the initiation of seismic soil liquefaction. Struct. Saf. 24, 67-82. doi:10.1016/ S0167-4730(02)00036-X

Coburn, A. W., and Spence, R. J. S. (1992). Earthquake Protection. Wiley. Available at: http://books.google.de/books?id=8L83AQAAIAAJ formal loss collection mechanisms within governments, and thus the breakdown of secondary effects losses seen in the literature, has improved.

A few larger events such as Haiyuan 1920, Sumatra 2004, Great Kanto 1923, and Christchurch 2011 dominate the secondary effects seen since 1900; over 3,000 events of the almost 10,000 events have recorded secondary effects showing the additional importance of increased research in this field. As improved models for secondary effects of earthquakes continue to be created and better collection of loss statistics occur, the reanalysis of historic events should allow for scenario-based current and future effects of potential earthquake secondary effect cascading events to be analyzed, but also a potential check of the historical impacts. As more data sources become digitized, the historical event reanalysis is also being improved by better amalgamation of older reports on the events. The CATDAT database represents a step to disaggregate such events and continued collection of the data in the future will continue to improve the past disaster disaggregation of secondary effect losses.

\section{AUTHOR CONTRIBUTIONS}

JD-the data analysis from CATDAT, studies into historical event losses, and secondary effect analysis. AS-tsunami analysis and general checking. FW-methodological changes, checks of analysis, editing and proofing diagrams and text, and secondary effect analysis. All authors have contributed to, read, modified, and approved the final manuscript.

\section{ACKNOWLEDGMENTS}

We acknowledge the support by Deutsche Forschungsgemeinschaft and Open Access Publishing Fund of Karlsruhe Institute of Technology.

Daniell, J. E. (2011). Damaging Volcanoes Database 2010 - The Year in Review: CEDIM Research Report 2011-02. Available at: http://www.cedim.de/ download/CATDAT_VOLC_Data_-_1st_Annual_Review_-_2010_-_James_ Daniell_-_02.02.2011.pdf

Daniell, J. E., Khazai, B., Wenzel, F., and Vervaeck, A. (2011a). The CATDAT damaging earthquakes database. Nat. Hazards Earth Syst. Sci. 11, 2235-2251. doi:10.5194/nhess-11-2235-2011

Daniell, J. E., Vervaeck, A., and Wenzel, F. (2011b). "A timeline of the socio-economic effects of the 2011 Tohoku earthquake with emphasis on the development of a new worldwide rapid earthquake loss estimation procedure," in Australian Earthquake Engineering Society 2011 Conference (Barossa Valley, Australia).

Daniell, J. E., Wenzel, F., Khazai, B., and Vervaeck, A. (2011c). "A country-by-country building inventory and vulnerability index for earthquakes in comparison to historical CATDAT damaging earthquakes database losses," in Australian Earthquake Engineering Society 2011 Conference (Barossa Valley, Australia).

Daniell, J. E., and Love, D. (2010). "The socio-economic impact of historic Australian earthquakes," in Australian Earthquake Engineering Society 2010 Conference (Perth, WA), 8.

Daniell, J. E., Schäfer, A., Wenzel, F., and Khazai, B. (2013). "Worldwide Losses from earthquake induced secondary effects and their implications for D-A-CH and insurance (in German), beitragsnr. 138, 13," in D-A-CH Tagung für 
Erdbebeningenieurwesen und Baudynamik (D-A-CH 2013), eds C. Adam, R. Heuer, W. Lenhardt, and C. Schranz (Wien, Österreich), 29-30.

Daniell, J. E., and Vervaeck, A. (2011). The 2011 Tohoku Earthquake - CATDAT Situation Reports 1-52. Available at: http://Earthquake-Report.com

Daniell, J. E., and Wenzel, F. (2014). "The production and implementation of socioeconomic fragility functions for use in rapid worldwide earthquake loss estimation," in Paper No. 490, 15th ECEE European Conference of Earthquake Engineering (Istanbul, Turkey).

Disaster Prevention Council, and Tokyo Metropolitan Government. (1985). Report on Earthquake Damage Estimation in Tama District. Tokyo, Japan: Disaster Prevention Council Report.

Dismuke, J. N., and Mote, T. I. (2012). "Approximate deaggregation method for determination of design earthquake magnitudes for Australia," in Proceedings of the 15th World Conference of Earthquake Engineering (Lisbon, Portugal).

Fire Disaster Management Agency Japan (FDMA). (2011). 2011 Tohoku Earthquake - Update of Damages - 1st-148th Version - 11th March 2011 to 9th September 2013 (in Japanese). Available at: http://www.fdma.go.jp/bn/2013/ detail/691.html

Flores, R. A. (1960). "Engineering aspects of Chilean earthquakes of May 21 and 22, 1960," in Proceedings of the 2nd World Conference of Earthquake Engineering (Japan).

Fuji, Y., and Satake, K. (2013). Slip distribution and seismic moment of the 2010 and 1960 Chilean earthquakes inferred from Tsunami waveforms and coastal geodetic data. Pure Appl. Geophys. 170, 1493-1509. doi:10.1007/ s00024-012-0524-2

Global Disaster Alert and Coordination System (GDACS). (2011). GDACS Alert for the Tohoku Earthquake. Available at: http://www.gdacs.org/report. aspx? eventtype $=\mathrm{EQ} \&$ eventid $=104706$

Goda, K., Mai, P., Yasuda, T., and Mori, N. (2014). Sensitivity of tsunami wave profiles and inundation simulations to earthquake slip and fault geometry for the 2011 Tohoku earthquake. Earth Planets Space 66, 1-20.

Godt, J., Sener, B., Verdin, K., Wald, D. J., Earle, P. S., Harp, E., et al. (2008). "Rapid assessment of earthquake-induced landsliding," in Proceedings of the First World Landslide Forum (Tokyo, Japan: United Nations University).

Goh, A. T. C., and Goh, S. H. (2007). Support vector machines: their use in geotechnical engineering as illustrated using seismic liquefaction data. Comput. Geotech. 34, 410-421. doi:10.1016/j.compgeo.2007.06.001

Iida, K., Cox, D. C., and Pararas-Carayannis, G. (1967). Preliminary Catalog of Tsunamis Occurring in the Pacific Ocean, HIG-67-10. Honolulu, Hawaii: Hawaii Institute of Geophysics, University of Hawaii, 275.

Ikeda, T., and Nakabayashi, K. (1996). "Relevant analysis of human casualties and building damage of the earthquake disaster (in Japanese)," in Social Safety Society Proceedings. Shizuoka, Japan, 163-166.

InaSAFE. (2013). InaSAFE Documentation - Release 1.2.0. Available at: http:// inasafe.org/

Instituto Hidrografico de la Armada. (1982). Maremotos en la costa de Chile. Instituto Hidrografico de la Armada, IHA Pub 3016. Valparaiso, Chile: Instituto Hidrografico de la Armada, 48.

Jibson, R. W. (2007). Regression models for estimating coseismic landslide displacement. Eng. Geol. 91, 209-218. doi:10.1016/j.enggeo.2007.01.013

Kawasumi, H. (1954). Intensity and magnitude of shallow earthquakes. Publ. Du Bur. Cent. Séismol. Int. A Trav. Sci. 19, 99-114.

Keefer, D. K. (1984). Landslides caused by earthquakes. Geol. Soc. Am. Bull. 95, 406-421. doi:10.1130/0016-7606(1984)95<406:LCBE>2.0.CO;2

Keefer, D. K. (2002). Investigating landslides caused by earthquakes - a historical review. Surv. Geophys. 23, 473-510. doi:10.1023/A:1021274710840

Khazai, B., Daniell, J. E., and Wenzel, F. (2011). The March 2011 Japan earthquake - analysis of losses, impacts, and implications for the understanding of risks posed by extreme events. Technikfolgenabschätzung Theorie Prax. 20, 22-33. Available at: http://www.tatup-journal.de/downloads/2011/tatup113_khual1a. pdf

Khazai, B., and Sitar, N. (2004). Evaluation of factors controlling earthquake-induced landslides caused by Chi-Chi earthquake and comparison with the Northridge and Loma Prieta events. Eng. Geol. 71, 79-95. doi:10.1016/ S0013-7952(03)00127-3

Kramer, S. L. (1996). Geotechnical Earthquake Engineering. Upper Saddle River, NJ: Prentice Hall.
Lander, J. F., Lockridge, P. A., and Kozuch, M. J. (1993). Tsunamis Affecting the West Coast of the United States, 1806-1992, KGRD no. 29, National Oceanic and Atmospheric Administration. Boulder, CO: National Geophysical Data Center, 242.

Lazo Hinrichs, R. G. (2008). Estudio de los Daños de los Terremotos del 21 y 22 de Mayo de 1960. Masters thesis.

Lockridge, P. (1985). Tsunamis in Peru-Chile. Boulder, CO: National Geophysical Data Center (NOAA).

Mai, M., and Beroza, G. (2002). A spatial random field model to characterize complexity in earthquake slip. J. Geophys. Res. Solid Earth 107, ESE 10-1-ESE 10-21. doi:10.1029/2001JB000588

Mancilla, L., and Mardones, L. (2010). El terremoto de 1960 en Castro, Imprenta Austral. Chile: Imprenta Austral de Temaco.

Marano, K. D., Wald, D. J., and Allen, T. I. (2010). Global earthquake casualties due to secondary effects: a quantitative analysis for improving rapid loss analyses. Nat. Hazards 52, 319-328. doi:10.1007/s11069-009-9372-5

Miles, S. B., and Keefer, D. K. (2009). Evaluation of CAMEL - comprehensive areal model of earthquake induced landslides. Eng. Geol. 104, 1-15. doi:10.1016/j. enggeo.2008.08.004

MunichRe. (1998). World Map of Natural Hazards. Munich Reinsurance Company.

Nadim, F., Kjekstad, O., Peduzzi, P., Herold, C., and Jaedicke, C. (2006). Global landslide and avalanche hotspots. Landslides 3, 159-173. doi:10.1007/ s10346-006-0036-1

National Police Agency Japan (NPA). (2011). Damage Situation and Police Countermeasures Associated with 2011 Tohoku District - Off the Pacific Ocean Earthquake. Available at: http://www.npa.go.jp/archive/keibi/biki/higaijokyo_e.pdf

NGDC/NOAA. (2010). Significant Earthquakes Database \& Significant Tsunami Database. Available at: http://ngdc.noaa.gov

Ohta, H., and Goto, N. (1985). Earthquake Loss Estimation Model: Vulnerability Analysis on a Household Level (in Japanese). Working Paper. Tokyo, Japan: Scientific Foundation.

Ohta, Y., Goto, N., and Ohashi, H. (1983). An empirical construction of equations for estimating number of victims by earthquakes. Zisin II 36, 463-466. doi:10.4294/zisin1948.36.3_463

Okada, Y. (1985). Surface deformation due to shear and tensile faults in a halfspace. Bull. Seismol. Soc. Am. 752, 1135-1154.

Osaka Prefecture. (1997). Osaka Earthquake Damage Estimation: Survey Report (in Japanese). Osaka, Japan: Osaka Prefectural Government.

Parker, R. (2013). Hillslope Memory and Spatial and Temporal Distributions of Earthquake-Induced Landslides. Doctoral dissertation, Durham University.

Rodriguez, C. E., Bommer, J. J., and Chandler, R. J. (1999). Earthquake-induced landslides: 1980-1997. Soil Dyn. Earthquake Eng. 18, 325-346.

Rothe, J. P. (1969). The Seismicity of the Earth 1953-1965, United National Educational, Scientific, and Cultural Organization (UNESCO). Paris, France: UNESCO, 312 .

Saint-Amand, P. (1961). Los Terremotos de Mayo, Chile 1960. China Lake, CA: Michelson Laboratories, US Naval Ordinance Test Station, 40. Technical Article 14, NOTS TP 2701.

Saitama Prefecture. (1982). Earthquake Damage Estimation: Research Report (in Japanese). Japan: Saitama Government Report, Saitama Prefecture, 1-356.

Scawthorn, C., Eidinger, J. M., and Schiff, A. (eds) (2005). Fire Following Earthquake, Vol. 26. USA: American Society of Civil Engineers.

Schaefer, A., Daniell, J., and Wenzel, F. (2015). M9 Returns - Towards a Pan-Pacific Tsunami Hazard Risk Model. Sydney: Australian Earthquake Engineering Society.

Schäfer, A. M., and Wenzel, F. (2017). Tsupy: computational robustness in Tsunami hazard modelling. Comput. Geosci. 102, 148-57. doi:10.1016/j. cageo.2017.02.016

Seed, H. B., and Idriss, I. (1971). Simplified procedure for evaluating soil liquefaction potential. J. Soil Mech. Found. Div. 97, 1249-1273.

Shi-zhong, H. (2010). Newly collected report on the 1933 Diexi Earthquake published in Jialingjiang Daily. Earthquake Res. Sichuan 3, 7.

Slingsby, A., Daniell, J. E., Dykes, J., and Wood, J. (2011). "Sharing insights on the impact of natural disasters using Twitter," in European Geosciences Union (EGU) (Ed.), Geophysical Research Abstracts, Vol. 13 (Göttingen, Germany: Copernicus Publications), EGU2011-9171. Available at: https://www.researchgate.net/ publication/258434425_Sharing_insights_on_the_impact_of_natural_disasters_using_Twitter 
Soloviev, S. L., and Go, C. N. (1975). A Catalogue of Tsunamis on the Eastern Shore of the Pacific Ocean [Dates Include 1513-1968]. Moscow: Academy of Sciences of the USSR, Nauka Publishing House, 204. (Canadian Translation of Fisheries and Aquatic Sciences no. 5078, 1984).

Talley, H. C. Jr., and Cloud, W. K. (1962). United States Earthquakes 1960. US Department of Commerce \& Coast and Geodetic Survey, U.S. Government Printing Office: Washington.

Tazieff, H. (1962). Quand la terre tremble (When the Earth Shakes). Paris: Edition Fayard, 11-100.

Tokyo Metropolitan Government. (1978). Report on Earthquake Damage Estimation in the Ward Districts of Tokyo: Disaster Prevention Council Report. Tokyo, Japan.

TsuDAT. (2013). Tsunami Data Access and Modelling Tool (TsuDAT). Available at: https://github.com/AIFDR/tsudat2

U.S. Coast and Geodetic Survey. (1962). Earthquakes in the United States in 1960. Technical Report.

U.S. Geological Survey (USGS). (2011, 2013). PAGER - Prompt Assessment of Global Earthquakes for Response. Available at: http://earthquake.usgs.gov/ earthquakes/pager/

World Agency of Planetary Monitoring and Earthquake Risk Reduction. (2013). QLARM. Available at: http://www.wapmerr.org/qlarm.asp
Yasuda, S., and Harada, K. (2014). "Measures developed in Japan after the 1964 Niigata earthquake to counter the liquefaction of soil," in 10NCEE, Paper No. 1778, Frontiers of Earthquake Engineering, July 21-25, 2014, Anchorage, Alaska.

Ye, Y., and Okada, N. (2001). "Improving management of urban earthquake disaster risks," in Earthquake Engineering Frontiers in the New Millennium, eds B. F. Spencer Jr. and Y. X. Hu (Netherlands: Swets and Zeitlinger), $113-118$.

Conflict of Interest Statement: The authors declare that the research was conducted in the absence of any commercial or financial relationships that could be construed as a potential conflict of interest.

Copyright (c) 2017 Daniell, Schaefer and Wenzel. This is an open-access article distributed under the terms of the Creative Commons Attribution License (CC $B Y)$. The use, distribution or reproduction in other forums is permitted, provided the original author(s) or licensor are credited and that the original publication in this journal is cited, in accordance with accepted academic practice. No use, distribution or reproduction is permitted which does not comply with these terms. 